\title{
ТРАНСПОРТНІ ТЕХНОЛОГIÏ
}

\section{ФОРМУВАННЯ ПРОЦЕСУ ДОСТАВЛЕННЯ МЕБЛІВ У РОЗІБРАНОМУ ВИГЛЯДІ}

\author{
Савченко Л. В. ${ }^{1}$, Семерягіна М. М. ${ }^{1}$, Савченко I. М. $^{2}$ \\ ${ }^{1}$ Національний авіаційний університет, ${ }^{2}$ Національний транспортний університет
}

Анотація. У статті наведені переваги та недоліки під час доставлення на продаж меблевих виробів у розібраному вигляді. Здійснено економічний аналіз логістичних витрат, які супроводжують ией перехід, на прикладі експортних потоків украйнського виробника. За основу прийнято підхід бенчмаркінгу, а саме досвід всесвітньо відомої компанії IKEA.

Ключові слова: логістичні витрати, перевезення меблів, досвід IKEA.

\section{Вступ}

Компанія-виробник незмінно стикається 3 необхідністю переглянути свої логістичні процеси, щоб зменшити відповідні витрати. Особливо це стосується експортних компаній. Ми проаналізуємо досвід світового меблевого гіганта, відомого своєю успішною стратегією, зокрема в галузі логістики.

Основною сферою діяльності компанії IKEA $€$ продаж меблів у розібраному вигляді. Споживачі беруть участь у процесі створення меблів під час безпосереднього збирання. Відмова від продажу зібраних меблів дозволяє суттєво зекономити на логістичних витратах, зокрема не лише під час транспортування, але й в процесі зберігання на складах системи розподілу.

\section{Аналіз публікацій}

На жаль, наукових статей щодо аналізу логістичних витрат під час перевезення меблів майже немає. Існує багато публікацій рекламного, аналітичного та пояснювального характеру щодо перевезення та збирання меблів. В [1] автори подають загальні поради щодо оптимізації логістики під час перевезення меблів.

Робота [2] присвячена аналізу процесів, що відбуваються під час збирання меблів споживачами, зокрема впливу якості інструкції на швидкість збирання чоловіками та жінками.

Роботи [3-6] дозволили оцінити якість та ефективність логістичних процесів компанії IKEA. Визначення переваг та недоліків переходу на виробництво та продаж меблів у розібраному вигляді було зроблено у [7].

Таким чином, можна спостерігати дефіцит знань щодо логістичних процесів під час перевезення меблів як у зібраному, так і в розібраному вигляді.

\section{Мета і постановка завдання}

Зважаючи на недостатню кількість наукових розробок щодо логістичних процесів під час перевезення меблів як у зібраному, так і у розібраному вигляді, метою статті $\epsilon$ економічний аналіз переваг та недоліків переходу на виробництво та продаж розібраних меблів, а також розрахунок економічної доцільності такого заходу для конкретного підприємства.

\section{Аналіз логістичних витрат та вигод}

1. Аналіз досвіду побудови логістичних проиесів IKEA

IKEA - найбільший у світі роздрібний продавець предметів меблів, що має понад 20 дистриб'юторських центрів, які обслуговують 355 магазинів у 29 країнах. Компанія посідає 40 номер у списку найцінніших світових брендів за версією журналу Forbes. Логістика такої розгалуженої мережі має бути побудована бездоганно для утримання лідерських позицій з року в рік.

Збирання «зроби сам» («Self-assembly») знижує витрати на пакування. Деталі меблів IKEA упаковують до зручних та ефективних плоских коробок, що здешевлює транспорту логістику, оскільки вони займають менше місця у вантажних відсіках автомобілів, вагонів та суден, максимізуючи кількість продукції, яка може бути відвантажена, та мінімізуючи витрати на виконання замовлення.

3 іншого боку, унікальне пакування займає менше місця під час зберігання, що дозволяє зменшити потрібну кількість складських площ, зменшуючи витрати складської логістики. Зменшені транспортно-складські витрати напряму впливають на відпускну ціну, що так само збільшує кількість клієнтів [3]. Вдосконалення внутрішніх процесів ланцюга доставлення, зокрема пакування, скла- 
дання та транспортування, сприяє досягненню мети скорочення загальних витрат.

Крім того, ефективне пакування та мінімізація порожнього місця в процесі перевезення позитивно впливає на навколишнє природнє середовище. Плоскі коробки та перевезення в розібраному вигляді дозволяють перевозити більше товарів за одну поїздку. Під час перевезення автомобільним транспортом це дозволяє використовувати менше транспортних засобів на дорозі та дозволяє зменшувати кількість викидів $\mathrm{CO} 2$ [5].

Згідно з оцінками компанії, обсяг перевезень був би в шість разів більше, якщо б товари IKEA відправляли в зібраному вигляді [6]. Позиція всіх працівників IKEA $є$ такою: «Ми не хочемо платити за доставлення повітря» [7].

2. Економічний аналіз доиільності переходу на виробництво та продаж товарів у розібраному вигляді (на прикладі експортних потоків TOB «NNN» (назва змінена з міркувань конфідениійності))

Доставляючи меблі в розібраному вигляді, компанія пропонує покупцеві принципово інший продукт, зокрема набір деталей, які ще потрібно зібрати і встановити в приміщенні, завершивши всі попередні роботи. Отже, в цьому випадку покупець залучається до процесу виробництва на його кінцевому етапі.

Вищеподаний досвід IKEA з вирорбництва та продажу розібраних меблів, що дозволяє знизити транспортні та складські витрати, розглянемо щодо компанії ТOB «NNN»одного 3 лідерів вітчизняного виробництва меблів для ванних кімнат.

Оскільки в процесі переходу до перевезення розібраних меблів найбільшу увагу приділяють саме експортним потокам, розглянемо типові параметри експортного доставлення.

Характеристики типового відправлення на експорт:

1) кількість місць, що завантажуються окремо, -411 одиниць;

2) вартість товарів в одній відправці приблизно 30000 євро;

3) обсяг замовлення, що завантажується до автомобіля, - приблизно 75 м куб.;

4) вага замовлення, що завантажується до автомобіля, - близько 10 т.

Майже завжди для перевезення експортних відправлень замовляють вантажівки, вантажопідйомністю 20 т, 3 корисним об'ємом кузова 86 м куб. Характеристики відправлення демонструють, що обмежувальним чинником для завантаження $€$ корисний об'єм, а не вантажопідйомність. Меблі завантажуєть за допомогою рокл 3 великим застосуванням ручної праці. Завантаження автомобіля на експорт здійснюється в середньому за чотири години.

Усі меблі TOB NNN постачаються споживачам у зібраному вигляді. Клієнт має лише прикрутити ручки та зняти запобіжні плівки 3 фасадів та меблів.

Для кожного виду меблів підбирається оптимальний пакувальний матеріал:

- повітряно-бульбашкова плівка використовується для пакування скла і дзеркал;

- поролоном і спіненим поліетиленом захищають поліровані поверхні;

- картон, зафіксований скотчем, захищає кути, що виступають, на предметах меблів;

- картонні коробки використовують для пакування невеликих предметів (світильники, деяку фурнітуру);

- меблі, що пакують до картонних коробок, рекомендується додатково обмотати стрейч-плівкою для захисту від вологи.

Розглянемо переваги та недоліки переведення TOB NNN на виробництво та продаж меблів у розібраному вигляді [7].

До переваг належать:

1) зменшення обсягу товару, що зберігається на складі (зменшення складських витрат, складського персоналу, складських площ, обсягу запасів).

За рахунок зменшення обсягу готового продукту можливо суттєво зменшити складські площі, зайняті запасами готової продукції у TOB NNN, а також у експортних клієнтів. У разі зменшення обсягу виробу мінімум на $50 \%$ можна досягти зменшення складських площ приблизно на $30 \%$ на складі готової продукції TOB NNN. Експортні клієнти також зможуть скоротити площі, зайняті продукцією ТОВ «Мойдодир», на 30 \%, що позитивно позначиться на собівартості їхніх послуг, а отже, на прибутку та рентабельності. Нині складське приміщення, яким володіє TOB NNN, можна здати в оренду приблизно за 2 грн/м² на добу.

Середній обсяг експортних відправлень, що зберігаються на складі, складає $200 \mathrm{~m}^{3}$. Зменшення обсягу готової продукції на 30 \% завдяки переходу на продаж розібраних меблів дозволить заощадити 33 м² $^{2}$

Отже, за умови вартості оренди, що складає 2 грн/м² на добу, є можливість додатково заробити 24090 грн на рік. 
2. Збільшення коефіцієнта статичного використання вантажопідйомності автомобіля (зменшення обсягу перевезеного «повітря», збільшення кількості товару, що може бути перевезений транспортним засобом, зменшення питомих витрат на перевезення одиниці товару, зменшення загальних витрат на доставлення за певний період).

Порівняємо схеми доставлення меблів до Казахстану у зібраному (сучасний стан) та розібраному (запропоноване рішення) вигляді.

Як зазначено, на сьогодні постачання здійснюється автомобілями 86 м$^{3}$. Оскільки в середньому кожен клієнт замовляє доставлення 2,3 рази на рік, зменшення кількості поставок $€$ нераціональним.

Отже, для збереження кількості поставок на рік, але за умови переходу на доставлення меблів у розібраному вигляді партія відправлення буде суттєво зменшена в обсязі приблизно до $40 \mathrm{~m}^{3}$. Замовляти індивідуальний автомобіль для транспортування 3 України до Казахстану такої партії невигідно, отже, пропонується знайти автомобіль до завантаження (таким чином, формується збірний вантаж з України до Казахстану). Вартість перевезення у цьому разі зменшується приблизно на 35 \%, як порівняти з доставленням в автомобілі $85 \mathrm{~m}^{3}$.

Різниця у витратах складає 690300 грн на рік.

3. Зменшення кількості виробничих процесів, пов'язаних зі збиранням (склейкою) меблів у виробника (зменшення годин на виробничі процеси, що зменшує собівартість товару у виробника).

Відомо, що на збирання середнього товаpy TOB NNN один працівник має витратити 35 хвилин. За середньої заробітної плати працівника, що залучений до цього процесу, 10000 грн збирання 1 комплекту коштує 36,25 грн. На збирання всіх казахстанських товарів TOB NNN витрачає 417165 грн на рік (заробітна плата працівника, що здійснює збирання).

Але $\epsilon$ й суттєві недоліки, що ускладнюють логістичну схему, а також призводять до додаткових або збільшених витрат на ії функціонування:

1. Збільшення обсягу необхідного пакування частин меблів (збільшення витрат на пакувальні матеріали).

Необхідно зазначити, що якісне пакування $є$ своєрідною візитівкою підприємства, зокрема для оптового покупця.
Створення схем пакування меблевих виробів $\epsilon$ завершальним етапом формування конструкторсько-технологічної документації. Це дуже трудомісткий процес, який на абсолютній більшості меблевих підприємств здійснюється власноруч працівниками. Програмного забезпечення для його ефективної автоматизації, зокрема інтегрованого зі спеціалізованими САПР, на ринку практично не існує.

У разі серійного виробництва на створення документації на пакування витрачається великий відсоток часу від загального терміну проектування самого виробу. У випадку ж індивідуального виробництва документація на пакування зазвичай не розробляється зовсім, оскільки в разі формування замовлень власноручне проектування пакування зайняло б надто багато часу. Отже, пакування здійснюється на місці самим пакувальником.

Конструювання пакування не відрізняється від процесу конструювання будь-якого іншого виробу і є процесом створення просторової конструкції, що забезпечує насамперед захист вмісту від зовнішніх умов під час зберігання та транспортування. Однак пакування повинно мати і такі додаткові властивості щодо розбірних меблів: забезпечення зручності перенесення і перевезення покупцем, відкриття опаковання та вилучення вмісту, а також інформаційну, естетичну і рекламну функції. Також важливими $є$ й екологічні іiї властивості.

Необхідно враховувати призначення пакування залежно від місця реалізації товару: для далекого транспортування міцніше, а для реалізації у власному магазині полегшене.

Найбільш слабким (найбільш пошкоджувальним) місцем пакування $є$ кути і кромки пакетів, особливо у великогабаритних і важких виробів. Існує багато способів додаткового захисту вмісту, вибір яких здійснюється відповідно до умов надійності й економіки 3 обов'язковою експериментальною перевіркою. Оскільки меблі на складі зберігаються стопами, інформація щодо конкретного виробу, необхідна для визначення виробника, наноситься на бічні і лицьовий бік пакета. 3 усіх видів пакування корпусних меблів і багатьох інших виробів найбільше і заслужене поширення в світі отримав гофрокартон. Картонне пакування надійне й технологічне, акуратне, легко маркується за допомогою написів і наклейок, екологічно чисте і добре піддається утилізації. 
Загальною тенденцією в сучасному пакуванні товарів $є$ використання найновітніших матеріалів і технологій, зокрема різних видів друку, наклейок, голографічних, пінопластів, «швидких» клеїв, наприклад контактних та клеїв-розплавів, нетканих і тканих матеріалів, полімерних плівок, наприклад термоусадочних, що розтягуються, і пухирчастих, різних застібок, пластикових пакетів тощо.

Найбільш простим та поширеним способом скріплення короба $є$ липкі стрічки типу
«Скотч», різної ширини і щільності. У деяких випадках можна рекомендувати ці ж стрічки, армовані склониткою. Нанесення стрічки здійснюється за допомогою відповідних пакувальних приладів - «диспенсерів». В інших країнах часто використовують стрічки із заздалегідь нанесеним товарним знаком, назвою і вихідними даними підприємства-виготовлювача меблів.

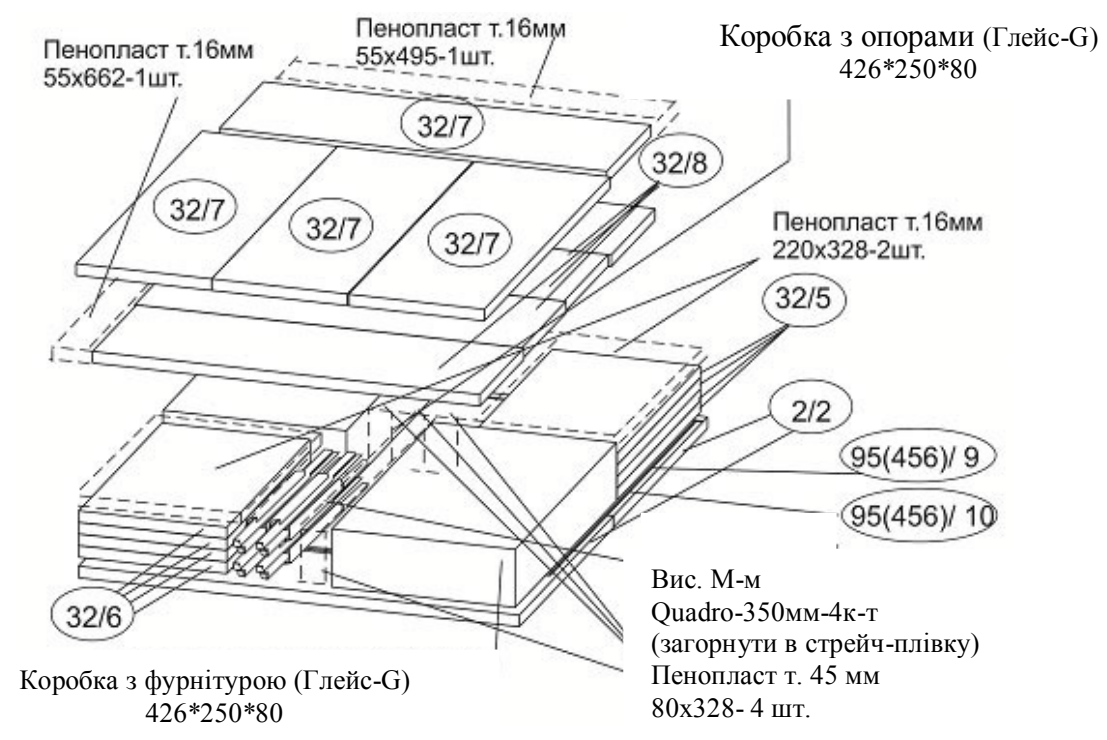

Рис. 1. Приклад схеми пакування

Також використовують для стягування пакетів поліпропіленові стрічки, що з'єднуються спеціальними замками, металевою скобою або зварюванням. Останнє рішення, безумовно, можна вважати найбільш досконалим. Встановлення замків здійснюється власноруч, а встановлення скоб і зварювання - за допомогою ручних машинок або спеціальних верстатів. Для закриття коробів використовують відповідні степлери і степлерні прилади.

Як пакувальний матеріал на TOB NNN застосовують:

1) картон (15 грн на 1 пакування);

2) ПВХ-плівку (5 грн на 1 пакування);

3) папір (2 грн на 1 пакування);

4) повітряно-бульбашкову плівку (8 грн на 1 пакування).

Зазначимо, що для пакування застосовують також інші матеріали, але їхня кількість буде такою ж, що і для перевезення меблів у розібраному вигляді. Отже, не беремо їх до уваги.

Можемо розрахувати, що на 1 товар ТОВ NNN, що відправляють на експорт, витрачається 30 грн.
Якщо здійснити доставлення в розібраному вигляді, витрати матеріалу збільшаться до 45 грн.

Розрахуємо збільшення вартості витрат на пакувальні матеріали:

1) доставлення у зібраному вигляді 345240 грн;

2) доставлення у розібраному вигляді 517860 грн.

Отже, додаткові витрати на пакувальний матеріал складають 172620 грн.

2. Збільшення робіт 3 пакування частин меблів (збільшення кількості працівників, зайнятих пакуванням, збільшення їхньої заробітної плати).

Пакування здійснюється 1 працівником, у цьому випадку на 1 товар витрачається приблизно 12 хв, година роботи пакувальника коштує 35 грн.

Процес пакування в розібраному вигляді буде здійснюватися на деяких виробничих ділянках, відповідно до того, що підлягає пакуванню. Разом на пакування всього комплекту 1 готового виробу у розібраному ви- 
гляді необхідно використати приблизно 20 хв.

Таким чином, заробітна плата робітникам, що здійснюють пакування, складає на рік:

1) за умови перевезення в зібраному вигляді - 80556 грн;

2) за умови перевезення в розібраному вигляді - 134260 грн.

Збільшення витрат на заробітну плату пакувальникам складає 53704 грн на рік.

3. Потреба у детальній інструкції щодо збирання виробу (додаткова робота технолога, збільшення витрат на його заробітну плату). Важливим елементом в ланцюзі виробництва та споживання продукції повинні мати інструкції зі збирання виробів. Під час їх складання рекомендується мати на увазі таке:

- інструкція - складова частина товару, є частиною його ціни та сплачується покупцем;

- вона повинна бути акуратно оформлена та відповідати фірмовому стилю підприємства;
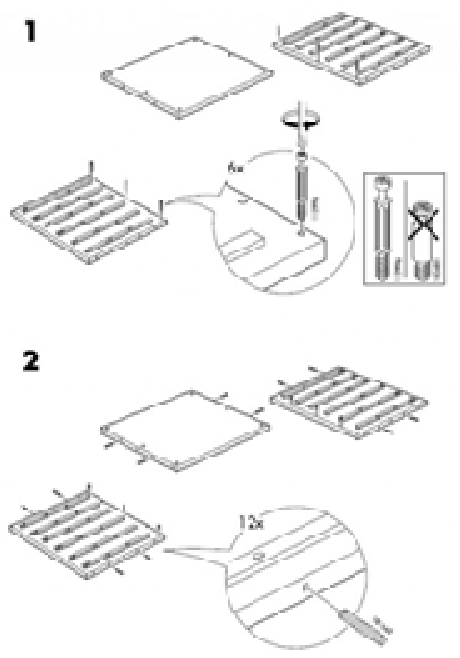

- якість поліграфії має кореспондуватися 3 класом (рівнем ціни) меблів;

- інструкція повинна бути зрозумілою пересічному покупцеві, а не розрахована тільки на фахівця;

- інструкція повинна містити ясні рекомендації з усіх питань, що можуть виникнути в процесі складання виробу, зокрема щодо процесу розкриття опаковання, організації робочого місця, послідовності операцій, матеріалів та інструментів, що використовувались, зручних і безпечних прийомів роботи;

- якщо виріб має варіанти компонування, то необхідно їх навести;

- бажано залучити до написання інструкції літературного і художнього редакторів або використати сучасні комп'ютерні редакторські програми;

- показником правильно оформленої інструкції є стислість і наочність (рис. 2).

3
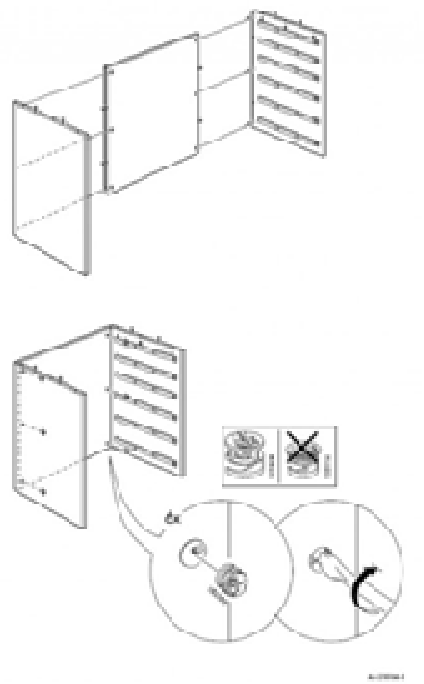

Рис. 2. Приклад наочної інструкції

Для забезпечення раціонального виконання завдання зі складання інструкції зі збирання, а також комплектації та специфікації товарів пропонуємо вкласти кошти в програмний продукт БАЗИС 10 [8]. Витрати, які несе підприємство у разі придбання цього програмного продукту, мають такі складові:

1) вартість ліцензії на програму 57000 грн (одноразово);

2) вартість технічного супроводу, зокрема оновлення - 5000 грн (щорічно);

3) вартість навчання персоналу роботі в програмі (250 грн на годину на 1 працівника, разом 2,5 000 грн одноразово).

4. Необхідність збирання меблів у компанії-отримувача (необхідність у персоналі, місцях та інструментах для збирання, що додає витрат у місці приймання товару).

Ці витрати можуть не мати місце, якщо меблі у розібраному вигляді надходять не лише до мережі розподілу, аде й до кінцевого споживача.

Якщо ж перед продажем кінцевому споживачу меблі мають бути зібрані, витрати на збирання можуть бути частково компенсовані можливістю здання в оренду вільних складських площ.

На нашу думку, меблі будуть поставлятися в розібраному вигляді аж до кінцевого споживача.

5. Зменшення прибутку з одиниці виробу за фіксованої рентабельності виробництва. 


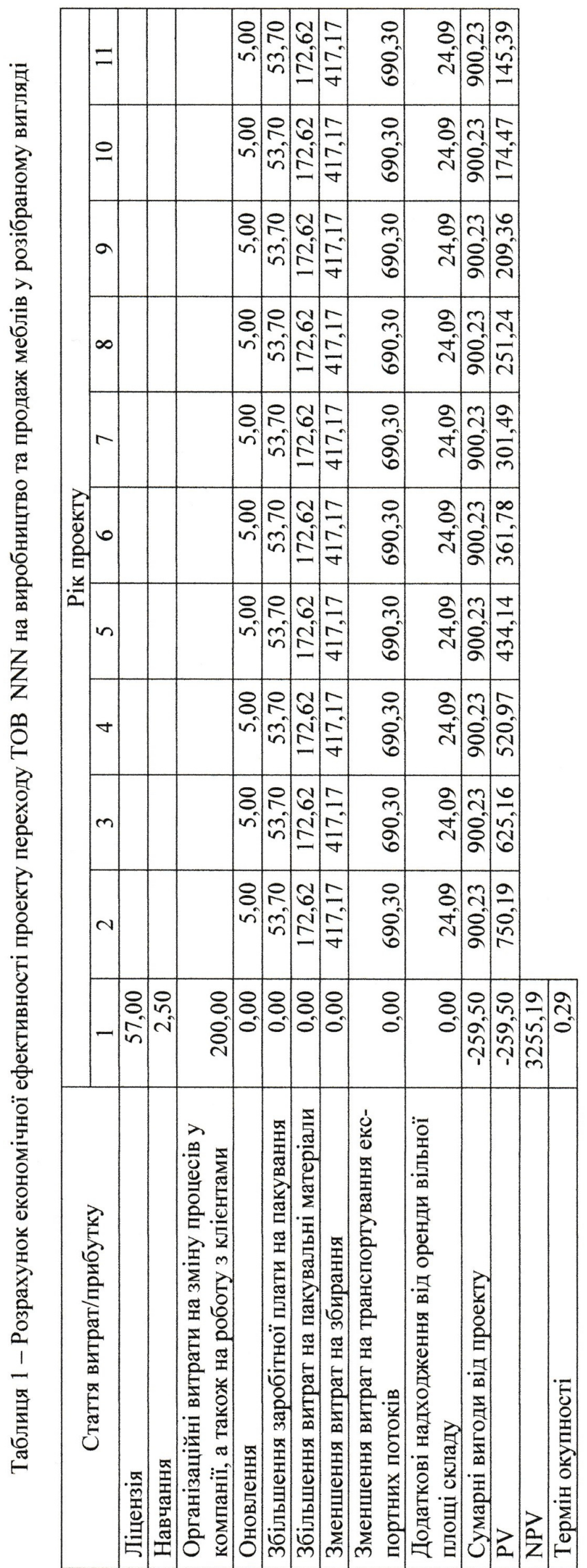


Ці додаткові витрати стосуються прибутковості бізнесу. Так, якщо стандартна товарна націнка складає $15 \%$, прибуток з більш коштовних товарів буде більшим, ніж для дешевих. Отже, в разі зменшення собівартості виробництва меблів і фіксованого рівня рентабельності прибуток від продажу товарів буде меншим. Проте в більшості випадків зменшення прибутку компенсується збільшенням обсягів продаж, адже товари 3 меншою відпускною ціною зазвичай охоплюють більшу частку ринку, ніж їхні більш коштовні аналоги.

6. Необхідність зміни бізнес-процесів, посадових інструкцій, штату компанії під відповідні зміни.

Допускаємо, що витрати складають у грошовому еквіваленті 200000 грн одноразово.

Розрахуємо тепер економічну ефективність проекту переходу на виробництво та продаж меблів у розібраному вигляді. Для цього застосуємо стандартну методику з обчисленням величини дисконтованих доходів (PV) і чистого зведеного ефекту (NPV-Net Present Value або ЧДД (чистий дисконтований дохід)), що розраховують за формулами

$$
\begin{aligned}
& P V=\sum_{t=1}^{T} \frac{P_{t}}{(1+r)^{t}} \\
& N P V=\sum_{t=1}^{T} \frac{P_{t}}{(1+r)^{t}}-I C,
\end{aligned}
$$

де $P_{t}$ - різниця між майбутнім вхідним і вихідним грошовими потоками в період $\mathrm{t}$ (чистий прибуток); IC - початкові інвестиційні витрати (вихідний грошовий потік); $T-$ iнвестиційний горизонт (кількість періодів, протягом яких виникають грошові потоки); $t$ - відповідний період; $r$ - ставка дисконтування (зазвичай вибирається ставка за банківськими депозитами 3 аналогічним терміном Т).

Розрахунок показників ефективності проекту надано в табл. 1

Навіть у перший рік сумарні економічні переваги переходу на доставлення експортної продукції до Казахстану перевищують додаткові витрати, що виникають. Отже, такий захід є економічно доцільним. Термін окупності - 0,29 роки (приблизно 3,5 місяці), враховуючи рік на реорганізацію бізнеспроцесів $-1,29$ роки.

\section{Висновки}

Відповідно до результатів теоретичних досліджень та практичного застосування вищенаведених спостережень, можна стверджувати, що:

1) перехід на виробництво та продаж меблів у розібраному вигляді передбачає суттєві витрати на реінжиніринг логістичних процесів на складі та під час транспортування. Ці аспекти необхідно враховувати як у виробника, так і в дистриб'ютора або іншого учасника мережі розподілу;

2) економічні переваги переходу на виробництво та продаж меблів у розібраному вигляді є суттєвими завдяки зменшенню складських площ та обсягів ручної праці на збирання меблів на виробництві та на транспортування меблів у мережі розподілу;

3) ефект економії транспортних витрат буде більш суттєвим, якщо більша частина транспортних витрат стане частиною вартості продукції. Так, за умов зовнішньоекономічних стосунків цей ефект буде більш помітним і призведе до швидкого окуплення інвестицій проекту;

4) під час аналізу логістичного ланцюга, що містить виробника та всі ланки мережі, які реалізують його продукцію, необхідно брати до уваги додаткові витрати та додаткові прибутки всіх цих ланок. Адже захід, що може зменшити витрати у виробника, може також спричинити надмірні та/або небажані витрати в інших учасників ланцюга. Таким чином, рішення щодо переходу на виробництво та продаж меблів у розібраному вигляді необхідно приймати комплексно, тобто 3 урахуванням позиції кожного учасника логістичного ланцюга.

Як невисвітлені аспекти теми можна назвати пошук таких параметрів логістичної системи, за яких переведення виробничих та логістичних процесів на створення та продаж меблів у розібраному вигляді буде економічно доцільним.

\section{Література}

1. 5 Keys to Optimizing Furniture Logistics. Brian Hoey, 2018. URL: https://blog.flexis.com/5-keysto-optimizing-furniture-logistics (дата звернення: 10.10.2019).

2. Sex Differences in Furniture Assembly Performance: An Experimental Study. Wiking S., Brattfjell M. L., Iversen E. E., Malinowska K., Mikkelsen R.L. at all. 2015. URL: https://doi.org/10.1002/acp.3182 (дата звернення: 19.10 .2019$)$. 
3. IKEA supply chain: How does IKEA manage its inventory? URL: https://www.tradegecko.com/ blog/supply-chain-management/ikeas-inventorymanagement-strategy-ikea (дата звернення: 10.10.2019).

4. Flat packs, stacks and how we ship them. URL: https://www.ikea.com/ms/en JP/the ikea story/w orking_at_ikea/work_areas_logistics.html (дата звернення: 10.10.2019).

5. Essays, UK. (November 2018). The Supply Chain Strategies Of IKEA. URL: https://www.ukessays.com/essays/marketing/thesupply-chain-strategies-of-ikea-marketingessay.php?vref=1 (дата звернення: 10.10.2019).

6. Operations and Supply Chain Management, $15 \mathrm{e}$ (SIE). Richard B. Chase, Ravi Shankar, F. Robert Jacobs. McGraw-Hill Education, 2018. 822 p.

7. Savchenko L. V., Velychko A. V., Savchenko I. M. Efficiency of transport and warehouse processes for self-assembling furniture. IKEA experience. Проблеми підготовки професійних кадрів 3 логістики в умовах глобального конкурентного середовища. 3бірник доповідей. Київ: НАУ, 2019. 243-245 с.

8. Прайс-лист на программное обеспечение системы БАЗИС. URL: http://amirian.ua/ pokupka/prays/ (дата звернення: 19.10.2019).

\section{References}

1. 5 Keys to Optimizing Furniture Logistics. Brian Hoey. (2018). URL: https://blog.flexis.com/5keys-to-optimizing-furniture-logistics (accessed: 10.10.2019).

2. Sex Differences in Furniture Assembly Performance: An Experimental Study. Wiking S., Brattfjell M. L., Iversen E.E., Malinowska K., Mikkelsen R.L. at all. (2015). URL: https://doi.org/10.1002/acp.3182 (accessed: 19.10.2019).

3. IKEA supply chain: How does IKEA manage its inventory? (2018). URL: https://www.tradegecko.com/blog/supply-chainmanagement/ikeas-inventory-managementstrategy-ikea (accessed: 10.10.2019).

4. Flat packs, stacks and how we ship them. (2018). URL:

https://www.ikea.com/ms/en_JP/the ikea_story/w orking_at_ikea/work_areas_logistics.html (accessed: 10.10.2019).

5. Essays, U.K. (2018). The Supply Chain Strategies Of IKEA. URL: https://www.ukessays.com/essays/marketing/thesupply-chain-strategies-of-ikea-marketingessay.php?vref=1 (accessed: 10.10.2019).

6. Operations and Supply Chain Management, 15e (SIE). Richard B. Chase, Ravi Shankar, F. Robert Jacobs. (2018) McGraw-Hill Education. 822 p.

7. Savchenko L. V., Velychko A. V., Savchenko I. M. Efficiency of transport and warehouse processes for self-assembling furniture. IKEA experience. Problems of training professional logistics personnel in the global competitive environment. Collection of reports. 243-245 p.

8. System Software БАЗИС Price List. (2018). URL: http://amirian.ua/pokupka/prays/ (accessed: 19.10.2019).

Савченко Лідія Володимирівна, к.т.н., доцент кафедри логістики, Національний авіаційний університет, пр. Космонавта Комарова, 1, м. Київ, 03058, Україна, lidia_savchenko@ukr.net, тел. +38 067-932-15-69,

Семерягіна Мирослава Миколаївна, ст. викл. кафедри логістики, Національний авіаційний університет, пр. Космонавта Комарова, 1, м. Київ, 03058, Україна; semeryagina@ukr.net,

тел. +38 093-606-84-60,

Савченко Ігор Миколайович, аспірант кафедри «Транспортні системи та безпека дорожнього руху», Національний транспортний університет, вул. Михайла Омеляновича-Павленка, 1; 02000, Україна, м. Київ, savchenko@gmail.com, тел. +38 050-353-56-00.

\section{Shaping the process of unassembled furniture delivery}

Abstract. The problem. The article considers the problem of increasing the efficiency of logistics processes for furniture manufacture and its distribution system. The main focus is analisis of possibility and effectiveness of disassembled furniture producing and sale. Goal. The goal of the article was an economic analysis of the advantages and disadvantages of the transition to the production and sale of disassembled furniture, as well as the calculation of the economic feasibility of such an event for the Ukrainian enterprise. Methodology. The article displays a systematic look at the transition to the production and sale of furniture in a disassembled form. Thus, we are talking about serious reengineering of both production and logistics, management and communication processes. The systematic approach allows us to evaluate the advantages and disadvantages of switching to disassembled furniture not only for a specific production enterprise, but also for other participants in the supply chain in the distribution network. Results. It is determined that the transition to the production and sale of furniture in disassembled form entails significant costs for the reengineering of logistics processes in the warehouse and during transportation. Moreover, these aspects should be taken into account by both the manufacturer and the distributor or other member of the distribution network. The economic benefits of moving to the production and sale of disassembled furniture are significant due to the reduction of warehouse space, the reduction of manual labor for the assembly of furniture in production and the transportation of furniture in the distribution network. The effect of saving transport costs will be all the more significant the greater part of transport costs are in the cost of production. Originality. The article describes for the 
first time what additional costs and benefits a furniture manufacturer will have to deal with when moving to disassembled furniture. Practical value. The practical significance of the work is confirmed by experimental estimates for the current furniture manufacturer. A methodology from the article for analyzing economic advantages and disadvantages can be used for other furniture manufacturers wishing to repeat the path of IKEA.

Keywords: furniture transportation, advantages of disassembled furniture, disadvantages of disassembled furniture, IKEA experience, logistics costs, transportation costs, storage costs, economical effect, project analysis, logistics chain

Savchenko Lidiia Volodymyrivna, Ph.D., Associate Professor, Department of Logistics, National Aviation University, Cosmonaut Komarov Ave, 1, Kiyv, 03058, Ukraine; lidia savchenko@ukr.net, tel. +38 067-932-15-69,

Semeryagina Myroslava Mykolayivna, Sen. Lect., Department of Logistics, National Aviation University, Cosmonaut Komarov Ave, 1, Kiyv, 103058, Ukraine; semeryagina@ukr.net,

tel. +38 093-606-84-60,

Savchenko Igor Mykolayovich, postgraduate student, Department "Transport systems and road safety", National Transport University, st. Mikhail Omelyanovich Pavlenko, 1, Kiyv, 02000, Ukraine, savchenko@gmail.com, tel. +38 050-353-56-00.
Формирование процесса доставки мебели в разобранном виде

Аннотация. В статье показаны преимущества и недостатки при переходе на продажу мебельных изделий в разобранном виде. На примере экспортных потоков украинского производителя сделан экономический анализ логистических затрат, которые сопровождают этот переход. За основу принят подход бенчмаркинга, а именно опыт всемирно известной компании IKEA.

Ключевые слова: логистические расходы, перевозка мебели, опьт IKEA

Савченко Лидия Владимировна, к.т.н., доцент кафедры логистики, Национальный авиационный университет, пр. Космонавта Комарова, г. Киев, 103058, Украина; lidia savchenko@ukr.net, тел. +38 067-932-15-69,

Семерягина Мирослава Николаевна, ст. препод. кафедры логистики, Национальный авиационный университет, пр. Космонавта Комарова, г. Киев, 103058, Украина; semeryagina@ukr.net, тел. +38 093-606-84-60,

Савченко Игорь Николаевич, аспирант кафедры «Транспортные системы и безопасность дорожного движения», Национальний транспортный университет, ул. Михаила Омельяновича Павленко, 1, г. Киев, 102000, Украина; savchenko@gmail.com, тел. +38 050-353-56-00. 